FACTA UNIVERSITATIS

Series: Linguistics and Literature Vol. 18, $\mathrm{N}^{\mathrm{o}} 1,2020$, pp. 1-8

https://doi.org/10.22190/FULL2001001M

Original Scientific Paper

\title{
LAUGHTER IN WRITTEN SERBIAN LANGUAGE *
}

\author{
UDC 811.163.41'37
}

\author{
Jordana Marković ${ }^{1}$, Violeta Stojičić \\ ${ }^{1}$ University of Niš, Faculty of Philosophy, Serbian Department, Niš, Serbia \\ ${ }^{2}$ University of Niš, Faculty of Philosophy, English Department, Niš, Serbia
}

\begin{abstract}
Laughter is an expression of a person's mood. It belongs to the vocal articulation in humans. In literature (and in dictionaries) sometimes this manner of articulation needs to be depicted in words. Different languages have different inventories of sounds which evoke laughter in written language. In this paper, we discuss the inventory of sounds by which laughter is represented in writing in the Serbian language. Data were compiled from published dictionaries and literary works, and some were obtained through a survey. The data were analyzed to compile the inventory of this function and to record spelling practices and nuances in transcribing various forms of laughter (loud, silent, etc.).
\end{abstract}

Key words: laughter, sound inventory, transcription, Serbian

\section{INTRODUCTION}

In the dictionary Rečnik srpskohrvatskoga književnog jezika (RMS), cмex (Eng. laughter) is defined as the expression of good mood, pleasure or similar feelings in intermittent characteristic sounds, usually followed by short and expressive movements of the lips, face, eyes, etc. ${ }^{1}$. It represents an involuntary reaction, unlike ocmex (Eng. smile), which is defined as a manifestation of kindness, joy, pleasure or ridicule, expressed by the particular movement of facial muscles and the stretching of the mouth ${ }^{2}$. Accordingly, we can conceive of cмex within the auditory domain, and of ocmex within the visual. However, it would be more accurate to say that laughter is expressed by both voice and body movements, and can be perceived through the sense of sight and the sense

Submitted February 2, 2020; Accepted March 21, 2020

Corresponding author: Jordana Marković

University of Niš, Faculty of Philosophy

E-mail: jordana.markovic@ filfak.ni.ac.rs

${ }^{*}$ This article is dedicated to Maja Vukić, who was always smiling.

${ }^{1}$ [ИЗРАЖАВАњЕ, ПОКАЗИВАњЕ ДОБРОГ РАСПОЛОЖЕЬА, ЗАДОВОљСТВА ИЛИ СЛИЧНИХ ОСЕЋАЮА ИСПРЕКИДАНИМ КАРАКТЕРИСТИЧНИМ ГЛАСОВИМА, ПРАЋЕНИМ ОБИЧНО КРАТКИМ И ИЗРАЗИТИМ ПОКРЕТИМА УСАНА, ЛИЦА, ОЧИЈУ И СЛ.] (смех RMS)

2 [ИЗРАЗ ЉУБАЗНОСТИ, РАДОСТИ, ЗАДОВОљСТВА ИЛИ ПОДСМЕХА, КОЈИ СЕ ИСПОљАВА НАРОЧИТИМ ПОКРЕТОМ МИШИЋА ЛИЦА И РАЗВЛАЧЕњЕМ УСТА, СМЕШАК] ( 
of hearing, while a smile is a non-verbal facial expression manifested by movements only, and is perceived by the sense of sight.

In the entry of [SMILE], RMS includes words such as xoxom and xuxom [LOUD LAUGHTER], as well as кикот. The words полуосмех and полусмех are defined as [BARELY NOTICEABLE LAUGHTER]. Also in the sense of осмеx (along with the meaning nодсмеx [SNEER]), Serbian lexis includes nосмех, as well as осмешак and осмешкај, within whose entries one is referred to осмех. Certain dialects employ сме/смеј, усмивка, лезење (Stojanović, 2010). The dialectal form смеj is included in RMS.

In RMS, the entry прасак includes the sense [VOICE HEARD WHEN A SUDDEN LAUGHTER ERUPTS]; yet, the word прасак in this particular sense is commonly found in co-occurrence with the word смех, which is illustrated by the examples in the entry, such as Јои један прасак бучнога смијеха тамо доље кад је махнита младост изишла из пусте куће аnd Тек ито затворих за собом врата, а оно у ложи пуче трећи прасак смеја. The sound of прасак, namely the manner of transcription of the sound in written language, is the topic of this study. In different circumstances, different literary works and authors, the transcription is relatively different. The inventory of sounds used to represent this type of expression of human feeling points to the difficulties associated with this issue, as one must take into account the fact that there are different types of laughter, as well as the fact that different people laugh in different ways.

\section{DICTIONARY DATA}

In order to obtain the graphemic sample, we referred to dictionaries and a corpus of literary works. We also devised a questionnaire based on the data collected. Subsequently, the students of Serbian studies at the Faculty of Philosophy in Niš ${ }^{3}$ were interviewed and the data analyzed. The objective was to demonstrate the inventory of graphemic units, the spelling of their usage, and semantic modifications. In collecting the sample, we first referred to RMS. The following entries were found:

1. $x a$ (repeated multiple times), onomatopoeia [IMITATING GIGGLE OR LAUGHTER]; the dictionary records the verbs хахакати, хахакнути and хахати;

2. $x e$ interjection (usually repeated twice or multiple times) [IMITATING GIGGLE OR LAUGHTER]; e.g. - Хе, хе! - насмија се постолар. Шен. Хе, хе, хе задовољно се поче смешкати газда Симо;

3. $x u$ interjection (usually repeated twice) [IMITATING SHY, LIGHT AND RESTRAINED LAUGHTER];

4. $x o$ interjection (repeated multiple times) [IMITATING LAUGHTER]; e.g. $-X o, x o$, хо! надре се смијати;

5. $u x a$ interjection (prolonged: uxaaa) [IMITATING SUDDEN AND LOUD LAUGHTER];

6. uxaxa interjection [EXPRESSING LAUGHTER AND SHRILLS IN DANCE AND FESTIVITY].

The form $x y$ (sometimes repeated multiple times) is described as an interjection, but not in the sense of laughter of any kind; it is used to describe a) anger, reprimand, criticism, b) an unpleasant physical sensation, tiredness and the like, or c) as onomatopoeia to imitate a hooting sound. The interjection oxo-xo has a vowel at the initial position and is used to express dissatisfaction or a pleasant surprise, but there is no evidence that it may refer to

\footnotetext{
${ }^{3}$ For this we acknowledge our colleagues Tatjana Trajković and Aleksandra Janić.
} 
laughter. The interjection axa, ax expresses surprise, wonder, pleasure, joy, or contempt ${ }^{4}$, while $x M$ is an interjection which expresses ridicule. However, mockery is not the topic of this research ${ }^{5}$.

The data described is frequently absent from dictionaries of dialects. The reason for the exclusion of such material lies in the fact that the sound $/ \mathrm{x} /$ is not present in Serbian vernaculars, and quite often in the dictionaries there may be no entry under this particular letter. We have noted only $a-x a-x a$ as an interjection for imitating laughter, in Jovanović (e.g. Расмејал се: $a-x a-x a, a-x a-x a)$ and in Stojanović (e.g. Гушу-етел да си исцепи како ми се смејал). In the dictionary Rečnik srpskih govora Vojvodine the interjection $x a$ is described as imitation of laughter. The entries $x e$ and $x u$ refer to $x a$, which indicates identical senses. In this dictionary $x o$ is an interjection used in stopping a horse, while $x y$ is not recorded. In Govor Zaplanja, Marković $(2000,75)$ considers the sound $x$ absent from onomatopoeia, so that on is an interjection in jumping, while $\kappa u, \kappa u$ is the imitation of laughter ${ }^{6}$.

In view of that, judging by the lexicographic evidence, laughter is represented by the combination of graphemes $x a, x e, x u$ and $x o$. In the particular function there is no combination with the sound $y$.

\section{LITERARY DATA}

This section will describe a sample of illustrations from literary works; it should be noted that some examples may also be found in the dictionaries described above. There are many examples in Zona Zamfirova by S. Sremac, such as the following:

- Xахаха! - смеје се чорбаиија;

- Хехе! - смеје се Мане; -Хехе, - осмехну се Васка; - Хехе! - осмехну се презриво Таска;

- Хе-хе! - осмехну се Зона;

- Ихаа! - засмеја се тетка Дока;

- Ихаха! - засмеја се Зона;

- Ухухуху! - прсну у глуп смех измећарка на ове последње речи.

In Ibiš-aga by Sremac we found the example - Ex-cмеје се Ибиш-агa.

As the examples demonstrate, the writer regularly emphasizes that he is describing laughter with this form. Examples of such laughter-free forms testify to the need for this: - Ха! - одобрава Замфир; - Ха! - врти главом стари Замфир; - Ахаха! - зева Замфир; - Хехе! - снебива се Мане; - Хе, лагала је што је зборила? Не ли?

\footnotetext{
${ }^{4}$ The noun ахалук is described as shouting aha in ridicule, e.g. - Велики ахалук и смијех око Гана.

${ }^{5}$ The data in the six volume dictionary are sometimes updated in the one volume dictionary Rečnik srpskoga jezika, as the following:

1. $x a$ узв. (поновљено више пута) 'оном. за подражавање кикотања, гласног смејања'.

2. хе узв. (обично поновљено више пута) 'за подражавање смејања'.

3. $x и$ узв. (обично поновљено више пута) 'за изражавање уздржаног, стидљивог смејања'.

4. $x u$ - $x$ узв. 'оном. за изражавање хихотања, кикотања'.

5. хо узв. (понекад поновљено) 'за подражавање смеха'.

6. ихаха узвик за изражавање смеха, кикотања у игри и весељу.

${ }^{6}$ The entry загрохтатu in Rečnik srpskohrvatskog književnog i narodnog jezik as an illustration contains xa...! Ки-ки...! (RSANU 1968).
} 
In the short story Čiča Jordan, Sremac provides the following examples: - Axaaa! тој ли учите у чкољу, тој ли ве је учитељ научио? - дере се чича Јордан; - А гле, Гила! Пази Гила! Хахаха! Пази га како се сплео! - продера се чича Јордан. Obviously, the former does not constitute imitation of laughter, but in the latter there is reason to claim that it was either mockery and ridicule or pure laughter by Uncle Jordan regarding what happened to Gile.

Sremac uses these forms of laughter imitation in Pop Cira i pop Spira:

- Хахаха! - насмеја се гђа Габриела онако уплакана.

Бар ће имати ко ће обријати поп-Спиру. Хахаха! Његов рођени зет!

- Ха, ха, ха!-смеје се поп-Олуја.

- Хе-хе!- смеје се Нића.- „Све по 'ладу, да га не познаду!“ Ааа! Синовче, не ваља ти пос'о!

- Хе, хе! Фрајла-Јуло, а ви канда завирујете! Канда мене тражите! Баш сте најгириг! Ту сам, ту-смеје се Шаца демонски.

- Хе, хе! Ту сам, ту - понавља Шаиа.

- Хе, хе!-смеје се и снебива Аркадија.

- Хехе - смеје се домаћин - како не би', како не би'!

- A, није, мама! А шта ће ти наочари! Кога си требала да видиш, видела си га пре толико година. Хехехе.

-Ил' ако није био баш код самог господин... хе-хе, а он и није ту, него на путу,вели Нића, па врти главом.

Ej, да нисам само на дужности, дошло ми је да се и ја овако матор кеша прођаволим мало... Хе, хе! А шта би ми к'о фалило!?

-Охо-хо! - смеје се госпођа Перса.-Шта ми се то дало на смеј. Чисто вас престављам и гледам како, тако дебела, бацате кегле!! О жено, жено!

In this work, as in all others, the writer "must" emphasize that it is laughter because he uses the same or similar forms which do not evoke laughter, as in the example Охо - узвикну зачуђено и увређено поп Спира, па остави шешир.

Sterija Popović in Pokondirena tikva uses similar expressions, but less frequently than expected in the subject matter. His heroine Sara laughs $x a$ (repeatedly or once), as in the following: Хa, ха! Ја немецки питам како се находите; Ха, ха, ха! Ја мислим да се наши заљубљени нећеју посвађати; Ха, ха, ха, наш младожења хоће своју супругу с комплиментом ала бонер да пробира!; Ха, ха, ха! Ма chère, једва чека прстен; Ха, ха, ха! Ја мислим да се наши заљубљени нећеју посвађати.

Jovan and Fema laugh in a different manner:

Jovan: Хе, хе! Тако би' најпосле ја морао обући сукњу, кад би' се на моду дао; Fema: (Сари) Xu, хи, хи! ... Сун паурентр. As this is a dramatic act, it is not necessary to emphasize that it is laughter - as in the previous examples - these forms should actually be a laughter on stage, i.e. in reading.

As the examples indicate, Sremac's characters are characterized by laughter with $x a$ and $x e$, while Steria's characters also use $x u$. Sremac employs uxaa, uxaxa and yxyxyxy, and Steria uses oxo-xo. It could therefore be said that the basic type of laughter is the one marked with $x a, x e, x u$, while other forms illustrate the author's creativity, such as Иxaa, Иxaxa, Уxyxyxy and Oxo-xo. 


\section{SURVEY DATA}

For this study, with reference to the data collected from dictionaries, we devised a questionnaire which included a possible way of transcribing laughter. The questionnaire was distributed to students of Serbian. For laughter of the $x a$ type, all the respondents replied it was possible. In the opinion of $30 \%$ of the respondents, such laughter is used by (almost) everyone; 17\% replied it was the manner of laughter of most people. The $x u$ laughter was considered possible by $88 \%$ of the respondents. This is mostly the laughter of children (30\%), and, according to some respondents, of women (7\%). Although $75 \%$ replied that xo laughter was possible, 93\% believed that such laughter belonged to Santa Claus. As many as $97 \%$ of the respondents answered that xe laughter was possible, although this type of laughter did not belong to a particular type of speaker. The answers were mostly individual (e.g. evil individuals, children, the elderly, nobody, etc.).

That $x y$ laughter was not possible was the answer of $57 \%$ of the respondents, while $38 \%$ of the respondents considered possible. The answer to the question who laughed in this type of laughter was absent in $38 \%$ cases, $25 \%$ answered that no one laughed in such a manner and the other answers varied. In the opinion of $70 \%$ of the respondents, the laughter of the $\kappa u$ type was possible and mainly belonged to children $(25 \%)$, babies $(11 \%)$ or the elderly $(8 \%)$. Other answers varied.

Laughter recorded by the initial vocals of the type uxaaa was not possible in the opinion of $85 \%$ of the respondents, while laughing in $u x a j$ was not possible in the opinion of $90 \%$ of the respondents. The possibility of transcribing laughter with the initial vocal of the uxaaa type was slightly higher (41\% of the respondents were in favor and $58 \%$ against). Suggestions for laughter transcription models could include the following: хахаха; хахахаха; хахахахаха; ха-ха-ха; бyаxaxa; бyaxaxaxa; ayyy, xa, xa, xa; xaa, xaa; хуе, хуе; хуе, хуе, хуе; хxxx; ке, ке, ке; ксе, ксе, ксе.

$X a$ laughter was loud $(31 \%)$, normal $(13 \%)$, ordinary $(10 \%)$, honest $(8 \%)$, joyful $(8 \%)$, while $11 \%$ of the respondents considered it ironic. $X u$ laughter was said to be quiet (15\%), secretive (15\%), shy (13\%), while $8 \%$ considered it ironic. The laughter of the $x o$ type was roaring $(27 \%)$, joyous $(15 \%)$, loud $(8 \%)$, festive $(3 \%)$, New Year's $(3 \%)$. The laughter of the xe type was secretive (15\%), quiet $(7 \%)$, malicious $(10 \%)$, ironic / sarcastic / insidious (27\%), and there were numerous other individual responses (loud, nervous, humorous, etc.). Although the laughter of the xo type was attributed to Santa Claus, the answers to the question about what that laughter was were not general; apart from repulsive $(7 \%)$ and loud $(5 \%)$, there were many individual descriptions (perverted, sneaky, elderly, etc.). The $\kappa u$ laughter was defined as quiet laughter (20\%), as a giggle $(15 \%)$, with a lot of individual responses (affectionate, loud, harmless, timid, etc.).

Obviously, the most acceptable form of transcription of laughter, according to the survey, was laughter of the $x a$ type; the respondents believed that was how most people laugh and that it was a representation of ordinary loud laughter. The forms of $x u$ and $x e$ type were considered quiet, hushed, or ironic laugh. Other forms belong to individual usages. 


\section{GRAMMATICAL AND STYLISTIC STATUS}

The question of a grammatical definition of these forms may be raised. However, if the definition in RMS is taken as a relevant example, the question will seem superfluous, since in the dictionary all these forms are unambiguously classified as interjections within their entries.

Some entries emphasize that the lexemes represent onomatopoeia, although the definition of onomatopoeia offers no such possibility. Namely, it is usually defined as a set of sounds mimicking sounds from nature or sounds produced by animals by transforming them into articulate human speech. There is no mention of laughter in the definition of this figure of speech, and laughter is not used to illustrate this phenomenon. However, to support the fact that the aforementioned forms represent a certain form of onomatopoeia, we claim that onomatopoeia is the transformation of unarticulated cries and noise into articulated sound. Onomatopoeia is classified into the phonetic-phonological system of a particular language, but the choice of sounds in this function, if not already established, can be an individual realization. In relation to this problem, it should be noted that onomatopoeia is used to imitate sounds both in spoken and written language in an (almost) identical way, so we may say that when a stone falls into the water, бy $\hbar$ (Eng. splash) is heard, which will be written down as such in Serbian. However, when it comes to laughter, we have to bear in mind that the vocal realization and the written form do not coincide and that in fact the writing should evoke the vocal realization.

In the discussion of written language, we have noticed slight hesitation regarding the transcription of laughter. There are indications that transcription of laughter necessarily involves the grapheme $h$ combined with a vowel. As a rule, a vowel follows a consonant. All Serbian vowels can be found in this function, i.e. $x a, x e, x u, x o$, and Sremac used Yxyxyxy as well. The monosyllabic forms $(x a, x e, x u)$ are found as dictionary entries, but in the examples and literary texts discussed in this article, the forms are repeated twice or multiple times. There are also differences in the repetition. Sometimes such forms are separated by commas: $x a, x a$; $x e, x e$; sometimes written as one word, e.g. xexe, xexexe, xaxaxa, and sometimes separated by a hyphen (as a half-word), e.g. xe-xe. This points to the fact that in the case of the usage of monosyllabic forms with commas we can speak of the use of two (three, or more) words, in the case of composite writing of two or more compound words, and in the case of writing with a hyphen, we can speak of a halfsyllable if the combination is disyllabic. The use of multisyllabic forms, such as $x a-x a$ $x a-x a$ leads to a discussion beyond our study ${ }^{7}$. Vowels may sometimes be found in the initial position. A particular vowel can be repeated, e.g. Oxo-xo, Axa, Axaxa, Уxyxyxy, or combined with another vowel, e.g. Иxaа, Иxaxa. Only $u$ can be found in the role of another vowel. A vowel following a consonant can also be doubled or repeated multiple times, e.g. Иxaa, Иxaaa.

\footnotetext{
${ }^{7}$ The possibility of multiple hyphens is described in Pravopis srpskoga jezika, but the examples cited do not correspond to this model (Pravopis 2010: 128).
} 


\section{CONCLUDING REMARKS}

Laughter in the Serbian language is transcribed by the combination of the letter $x$ and vowels in a position following this consonant. In that position one usually finds the vowel $a$, and sometimes the vowels $e$ and $u$. The use of the vowels $o$ and $y$ is rare, but it is not unusual. In dialects, it is also possible to use $\kappa$ as a substitute for the lost $x$ since the sound $x$ is almost non-existent in the Serbian vernacular.

Spelling patterns are numerous and they are the result of individual realizations ( $x a$, $x a, x a ; x a x a ; x a-x a ; x a-x a-x a$, etc.). In fact, such forms are constrained by the phonological system of a language and their understanding is conditioned by the knowledge of the content of such a word in a particular language, in accordance with de Saussure's view that the connection between sound and meaning is arbitrary. This is the reason why in literary works the explanation is almost regularly added to such forms to explicitly state that it is laughter. The most common pattern representing typical laughter is $x a x a ; x a, x a$. The second most frequently used types are $x e$ and $x u$, which, as a rule, represent a quiet laughter.

As our resources have suggested, writers try to depict laughter of different people and different forms of laughter through the use of various sound patterns. The choice may be individual, as indicated by the survey, but it must be functional, i.e. clear to the reader to a certain extent.

\section{REFERENCES}

Jovanović, Vlastimir. 2004. „Rečnik sela Kamenice (kod Niša)“. Srpski dijalektološki zbornik, 51, 313-688. Beograd: Institut za srpski jezik SANU.

Marković, Jordana. 2000. „Govor Zaplanja“. Srpski dijalektološki zbornik, 47, 7-307. Beograd: Institut za srpski jezik SANU.

Petrović, Milena. 2017. „Onomatopejski klik, zvuci, eholokacija i apsolutni sluh“, Nasleđe 38, 329-341.

Pravopis srpskoga jezika. 2010. Novi Sad: Matica srpska.

Rečnik srpskih govora Vojvodine. 2000-2010. Novi Sad: Matica srpska, IK Tiski cvet.

Rečnik srpskohrvatskog književnog i narodnog jezika, 1968. Knj. 5. Beograd: Srpska akademija nauka i umetnosti.

Rečnik srpskohrvatskoga književnog jezika, Knj. 1-3, Novi Sad - Zagreb: Matica srpska - Matica hrvatska; 1967-1969; Knj. 4-6, Novi Sad: Matica srpska, 1971-1976; Drugo fototipsko izdanje 1990.

Rečnik srpskoga jezika. 2011. Novi Sad: Matica srpska.

Stojanović, Radosav. „Crnotravski rečnik“, Srpski dijalektološki zbornik, 57, Beograd: Institut za srpski jezik SANU.

\section{SMEH U PISANOM SRSKOM JEZIKU}

Smeh predstavlja izražavanje, pokazivanje dobrog raspoloženja. Obično se ispoljava isprekidanim karakterističnim glasovima. Uprkos činjenici da se svi ljudi smeju slično, u pisanom jeziku se u različitim jezicima smeh beleži različitim glasovima. Za analizu u ovome radu glasovni inventar kojim se beleži smeh u srpskom jeziku preuzet je iz publikovanih rečnika i književnih dela, a do nekih se došlo putem ankete. Tako prikupljena građa pokazala je inventar leksičkih modela u ovoj funkciji, a analizirana su i pravopisna rešenja i semantičke nijanse označene različitim glasovnim kombinacijama. Pokazalo se da je po pravilu smeh označen grafemom $h$ u kombinaciji sa jednim od pet standardnih vokala srpskog jezika iza suglasnika. Najčešce se kombinacijom ha (haha; hahaha; ha, ha; ha, ha, ha; ha-ha; ha-ha-ha i sl.) beleži uobičajeni smeh i tako se, po mišljenju anketiranih ispitanika, smeje većina ljudi. Sledeći su po frekventnosti oni označeni sa he i hi, za koje ispitanici tvrde da predstavljaju pritajeni, tihi smeh. Raritetno se smeh beleži sa ho i ispitanici tvrde da takav smeh odlikuje Deda Mraza. Veoma retko je smeh označen sa hu. Po anketi, tako se niko ne smeje (ili im nije poznato ko se tako smeje), ali 
da i ova kombinacija bude uvrštena, pobrinuo se Sremac - u njegovoj Zoni Zamfirovoj tako se smeje izmećarka Vaska. Manje je kombinacija sa inicijalnim vokalom tipa: oho-ho, aha, Ahaha, uhuhuhu, a drugi vokal mogao je biti i udvojen (ihaa).

Ključne reči: smeh, inventar glasova, tip, transkripcija, srpski 